\title{
Fine Needle Aspiration Cytology of Cutaneous Metastatic Lesions: A Clinico-Cytopathological Perspective in A Tertiary Hospital
}

\author{
Manisha Mohapatra*, Sridhara Satyanarayana and Turlapati SatyaPrakash Venkatachalam \\ Department of Pathology, Ganni Subha Laxmi Medical College and General Hospital, Lakshmipuram, India
}

\begin{abstract}
Background: Cutaneous metastasis refers to growth of cancer cells in skin from an internal malignancy which indicates an adverse prognosis for the cancer patient. Fine needle aspiration cytology (FNAC) plays a major role in early diagnosis of such lesions. The study was undertaken in a tertiary hospital in south India with an objective to analyze the cases diagnosed as having metastatic lesions by FNAC with special reference to cutaneous metastasis.

Methods: The study consisted of retrospective analysis of all the cases diagnosed in our hospital as having metastatic lesions in various locations based on FNAC over a period of 7 years of which cases with cutaneous metastatic lesions were studied in detail. FNAC was done following routine protocols, stained smears were examined and opined by experienced pathologists. The result was analyzed.

Result: A total number of 579 cases were diagnosed to be having metastatic lesions in various sites based on FNAC findings out of which 61(10.5\%; Female-44, Male-17) cases had cutaneous metastasis. Majority, 35/61 (57.2\%) cases was in 5th to 6th decade. Fifty eight ( $95.0 \%)$ of cases presented with metastasis in single site whereas $3(5.0 \%)$ cases had lesions in multiple sites. The commonest primary malignancy in females and males was carcinoma breast and carcinoma colon or lung respectively.

Conclusion: This study depicts the clinical and cytopathological findings of patients with cutaneous metastatic lesions with known or unknown primaries and highlights the utility of FNAC in diagnosing such lesions which helps the clinicians to take prompt decision for further therapeutic management.
\end{abstract}

Keywords: Fine Needle Aspiration Cytology, Cutaneous, Metastasis

\section{Introduction}

Cutaneous or skin metastasis refers to growth of cancer cells in skin from an internal malignancy which indicates adverse prognosis for the cancer patients. It occurs due to systemic spread of primary tumor through vascular or lymphatic channels. These lesions can appear as nodule, red patch or as a fibrous scar like plaque in skin. Though most of the malignant tumors can metastasize to skin but a few show higher propensities for cutaneous metastasis such as malignant melanoma, carcinoma of breast, lung, colon, rectum, ovary and oral cavity. The incidence of cutaneous metastasis varies from 0.5 to $10.4 \% .^{[1-5]}$ However, early diagnosis can be offered by fine needle aspiration cytology (FNAC) accurately in majority of these patients having known or unknown primary malignancies. The study was undertaken with an objective to analyze the cases diagnosed as having metastatic lesions by FNAC with special reference to cutaneous metastasis.

\section{Materials and Methods}

The study consisted of retrospective analysis of all the cases diagnosed as having metastatic lesions in various locations based on FNAC over a period of 7 years (Jan. 2009 to Dec. 2016 ) in Pathology department of which cases with cutaneous metastatic lesions were studied in detail. Following clinical examination, fine needle aspiration (FNA) had been done in all of these cases using 22 to 23 gauze disposable needle with a minimum of two passes. Both air dried and wet smears were prepared and stained by (Leishman) and Papanicolaou (Pap) stain respectively. Special stain like Periodic acid Schiff (PAS stain) was performed where ever it was required. Stained smears were examined and opined by experienced pathologists. The data pertaining to clinical and cytological examination findings were compiled and analyzed in percentage which are represented in tables and graphical charts.

\section{Result}

The study included a total number of 579 cases comprising 247 males and 332 females with the diagnosis of metastatic lesions in various sites based on FNAC findings. From the pie chart (Figure-1), it could be observed that maximum number, $474(81.9 \%)$ had metastatic lesions in lymph nodes followed by skin, 61(10.5\%) cases, visceral organs, 
$25(4.3 \%)$ and bone seen in $19(3.3 \%)$ of total 579 cases. Out of the 61 cases having cutaneous metastatic lesions, 17 cases were males and 44 were females with $\mathrm{M}: \mathrm{F}$ ratio being 1:2.6. The age and sex wise distribution of all the cases with cutaneous metastatic lesions are discerned in bar chart (Figure-2), from which it was found that majority, $20(32.7 \%)$ cases belonged to $41-50$ years followed by 15 $(24.5 \%)$ cases in 51-60 years and $14(23.0 \%)$ cases in 2130 years of age group. There were $6(9.8 \%)$ cases in $61-70$ years of age, $3(5.0 \%)$ cases each in 21-30 years and above 70 years of age. None of these cases were under the age of 10 years. The age range varied from 25 to 85 years and the mean age was calculated to be 49.6 years.

Table -1 depicts the clinico-pathological features of the 61 cases with cutaneous metastatic lesions from which it was evident that 58 (95.0\%) of total cases presented with metastatic lesion in single site whereas $3(5.0 \%)$ cases had more than one site involvement thus giving rise to total number of 64 lesions. Size of nodule varied from 0.8 to 11.0 $\mathrm{cm}$ and the average size of nodule was found to be $3.7 \mathrm{~cm}$. The most frequently observed site of cutaneous metastasis was chest wall followed by lesions over abdomen as seen in $37(57.8 \%)$ and $8(12.5 \%)$ of total 64 lesions. In $6(9.4 \%)$, $5(7.8 \%), 7(10.9 \%)$ and $1(1.6 \%)$ cases the lesions were seen over back, head and neck region, upper and lower extremities and genital region such as vulva respectively. Fifty one out of 61 cases $(83.6 \%)$ presented with single nodular lesion in skin and $10(16.4 \%)$ cases had multiple nodules. In majority, 42/61(68.8\% ) cases FNA cytosmears revealed features of adenocarcinoma followed by squamous cell carcinoma seen in 12/61(19.7\% ) cases. The rest of the cases showed features of poorly differentiated carcinoma, germ cell tumor, anaplastic carcinoma and papillary urothelial carcinoma which were observed in $3(5.0 \%)$, $2(3.3 \%), 1(1.6 \%)$ and $1(1.6 \%)$ cases respectively. Breast carcinoma was noted to be the most common primary in females as seen in $32,72.7 \%$ out of 44 cases and cervical cancer was the second most common primary tumor which was seen in 5, 11.3\% cases. However, in 4, 23.5\% out of 17 males, the primary tumor was located in lungs as well as in gastrointestinal tract like stomach/ colon and in 4 cases, the primary tumor site was unknown at the time of FNA diagnosis. In $56(92.0 \%)$ out of 61 cases the nodules were observed during or after the therapeutic course of treatment for primary malignancy where as $5(8.0 \%)$ cases presented with such lesions as first manifestations.

During this study we observed six interesting cases with cutaneous metastasis in unusual sites. Table -2 shows the detailed clinical and cytomorphological findings whereas figure $-3,4$ and 5 depict clinical images and microphotographs of FNA cytosmears of these six cases. Case no.1. shows a post operative and post chemotherapy treated case of carcinoma stomach with Krukenberg's tumor diagnosed as cutaneous metastatic carcinomatous deposit in left forehead region from gastric adenocarcinoma on FNAC (Figure $3 a$ and $3 b$ ) and case no. 2 is an old lady showing swelling over right lobe of thyroid alongwith a lump in right chest wall who had been offered the diagnosis of metastatic carcinomatous deposit in right chest wall possibly from follicular carcinoma thyroid on the basis of FNAC of right chest wall swelling and USG guided FNAC of thyroid swelling (Figure-3c and $3 \mathrm{~d}$ ). Case no. 3 is a post operative modified radical mastectomy (MRM) case of invasive ductal carcinoma of left breast who presented with an ulcerated nodule over the MRM scar mark and opined as local recurrence of invasive ductal carcinoma (Figure-4a and 4b ). Local recurrence is also considered as cutaneous metastasis due to systemic spread of cancerous cells. Neither the clinical nor the cytological findings were suggestive of skin adnexal tumor, the possibility of which was excluded. Case no. 4 is a case of carcinoma oesophagus presenting with nodular lesions over over chin and right upper arm which were subsequently diagnosed as cutaneous squamous cell carcinomatous deposit (Figure-4c and 4d). Case no. 5 is a rare case of carcinoma urinary bladder who presented with an erythematous nodule over left side of abdomen and diagnosed as metastatic papillary urothelial carcinomatous deposit in anterior abdominal wall from carcinoma urinary bladder on FNA findings (Figure- $5 \mathrm{a}$ and $5 \mathrm{~b}$ ). The sixth case was a challenging and rare female case who presented with subcutaneous nodule on left thigh which was subsequently opined as metastatic adenocarcinomatous deposit possibly from breast on FNAC (Figure 5c and 5d).

Though, there were no proper clinical details provided during the time of FNAC, but microscopically the cytomorpholgy of the lesion were highly suspicious of metastatic deposit from ductal carcinoma of breast. However, subsequent clinical examination and history revealed the past history of left MRM for carcinoma of left breast. Hence, finally the diagnosis was confirmed to be cutaneous metastastic adenocarcinomatous deposit from breast.

\section{Discussion}

Cutaneous metastasis is believed to be a systemic spread of primary malignancy through lymphatic embolization, haematogenous or contiguous dissemination and also due to direct implantation during surgical procedure. [6,7] Usually it develops late after the initial diagnosis of primary malignancy, hence indicates poor prognosis for majority of cancer patients. However, in some cases it may 
Table 1: Clinicopatholgical features of cutaneous metastatic lesions (N-61).

\begin{tabular}{|c|c|c|}
\hline Clinical features & Cytomorphology of metastatic lesions & Primary tumor site \\
\hline $\begin{array}{l}\text { i. Sites } \\
\text { a.Single site - } 58(95.0 \%) \\
\text { b. Multiple sites - } 3(5.0 \%) \\
\text { ii. Locations of cutaneous deposits } \\
\text { - Chest wall - } 37(57.8 \%) \\
\text { - Abdomen- } 8(12.5 \%) \\
\text { - Back- } 6(9.4 \%) \\
\text { - Head \& neck - } 5(7.8 \%) \\
\text { - Lower extremity- } 4(6.2 \%) \\
\text { - Upper extremity - } 3(4.7 \%) \\
\text { - Genital region - } 1(1.6 \%) \\
\text { iii. Nodule type } \\
\text { - Single - } 51(83.6 \%) \\
\text { - Multiple - } 10(16.4 \%) \\
\text { iv. Nodule size - } \\
\text { - Range - } 0.8 \mathrm{~cm} \text { to } 11.0 \mathrm{~cm} \\
\text { - Average size - } 3.7 \mathrm{~cm}\end{array}$ & $\begin{array}{l}\text { Pattern } \\
\text { i. Adenocarcinoma - } 42(68.8 \%) \\
\text { ii. Squamous cell carcinoma -12 (19.7\%) } \\
\text { iii. Poorly differentiated carcinoma-3(5.0\%) } \\
\text { iv. Germ cell tumor - } 2(3.3 \%) \\
\text { v. Anaplastic carcinoma-1(1.6\%) } \\
\text { vi. Urothelial carcinoma -1(1.6\%) }\end{array}$ & $\begin{array}{l}\text { i.Females } \\
\text { - Breast - 32(72.7\%) } \\
\text { - Cervix - 5(11.3\%) } \\
\text { - GIT - 3(6.8\%) } \\
\text { - Larynx - 1(2.3\%) } \\
\text { - Unknown - 1(2.3\%) } \\
\text { - Thyroid - 1(2.3\%) } \\
\text { - Extremity - 1(2.3\%) } \\
\text { ii. Males - } \\
\text { - Lung - 4(23.5\%) } \\
\text { - GIT - 4(23.5\%) } \\
\text { - Unknown - 4(23.5\%) } \\
\text { - Thyroid - 1(5.9\%) } \\
\text { - Liver - 1(5.9\%) } \\
\text { - Testis - 2 (11.8\%) } \\
\text { - Urinary bladder -1(5.9\%) }\end{array}$ \\
\hline
\end{tabular}

Table 2: Clinical and cytomorphological features of unusual cutaneous metastatic lesions.

\begin{tabular}{|c|c|c|c|c|c|}
\hline $\begin{array}{l}\text { Case. } \\
\text { No }\end{array}$ & Age, sex & $\begin{array}{l}\text { Site of cutaneous } \\
\text { metastasis }\end{array}$ & $\begin{array}{l}\text { Appearance } \\
\text { Size }\end{array}$ & FNAC findings & $\begin{array}{l}\text { Primary tumor } \\
\text { Histological type }\end{array}$ \\
\hline 1 & $45 \mathrm{~F}$ & Left forehead & $\begin{array}{l}\text { Nodular } \\
2 \times 1.5 \mathrm{~cm}\end{array}$ & $\begin{array}{l}\text { Loose clusters, tiny glands, } \\
\text { discretely scattered round, oval, } \\
\text { columnar malignant epithelial } \\
\text { cells showing scanty pale } \\
\text { basophilic vacuolated cytoplasm, } \\
\text { nuclar atypia and prominent } \\
\text { nucleoli. }\end{array}$ & $\begin{array}{l}\text { Carcinoma stomach } \\
\text { with Krukenerg } \\
\text { tumor }\end{array}$ \\
\hline 2 & $67, F$ & Right chest wall & $\begin{array}{l}\text { Nodular } \\
6.0 \times 6.0 \mathrm{~cm}\end{array}$ & $\begin{array}{l}\text { Sheets, clusters, acinar structures } \\
\text { of thyrofollicular cells exhibiting } \\
\text { mild nuclear atypia, prominent } \\
\text { nucleoli. }\end{array}$ & $\begin{array}{l}\text { Thyroid } \\
\text { Possibly Follicular } \\
\text { carcinoma }\end{array}$ \\
\hline 3 & $45, F$ & Left chest wall & $\begin{array}{l}\text { Multiple nodular } \\
\text { ulcerated swellings } \\
\text { along the MRM scar }\end{array}$ & $\begin{array}{l}\text { Loose clusters, nests, acinar } \\
\text { structures of malignant ductal } \\
\text { epithelial cells. }\end{array}$ & $\begin{array}{l}\text { Right breast } \\
\text { Invasive ductal } \\
\text { carcinoma }\end{array}$ \\
\hline 4 & $50, M$ & $\begin{array}{l}\text { i.Chin } \\
\text { ii. Right upper arm }\end{array}$ & $\begin{array}{l}\text { i. } 2.5 \times 2 \mathrm{~cm}, \text { nodular } \\
\text { ii. } 2.0 \times 1.5 \mathrm{~cm} \\
\text { nodular }\end{array}$ & $\begin{array}{l}\text { Sheets of round, oval, polygonal } \\
\text { malignant squamous cells } \\
\text { showing eosinophilic cytoplasm } \\
\text { with hyperchromatic nuclei and } \\
\text { high N:C ratio. }\end{array}$ & $\begin{array}{l}\text { oesophagus } \\
\text { Squamous cell }\end{array}$ \\
\hline 5 & $55, \mathrm{M}$ & Left abdomen & $3.0 \times 2.5 \mathrm{~cm}$, nodular & $\begin{array}{l}\text { Papillae, nests and clusters } \\
\text { of round ,oval epithelial cells } \\
\text { having amphophilic / vacuolated } \\
\text { cytoplasm, large round to oval } \\
\text { nuclei and prominent nucleoli. }\end{array}$ & $\begin{array}{l}\text { Urinary bladder } \\
\text { Papillary urothelial } \\
\text { cell carcinoma }\end{array}$ \\
\hline 6 & $50, F$ & Left thigh & $\begin{array}{l}\text { Ill defined, } \\
6.0 \times 6.0 \mathrm{~cm}\end{array}$ & $\begin{array}{l}\text { Abundant cellularity exhibiting } \\
\text { cytomorphology of malignant } \\
\text { ductal epithelial cells. }\end{array}$ & $\begin{array}{l}\text { Left breast Invasive } \\
\text { ductal carcinoma }\end{array}$ \\
\hline
\end{tabular}




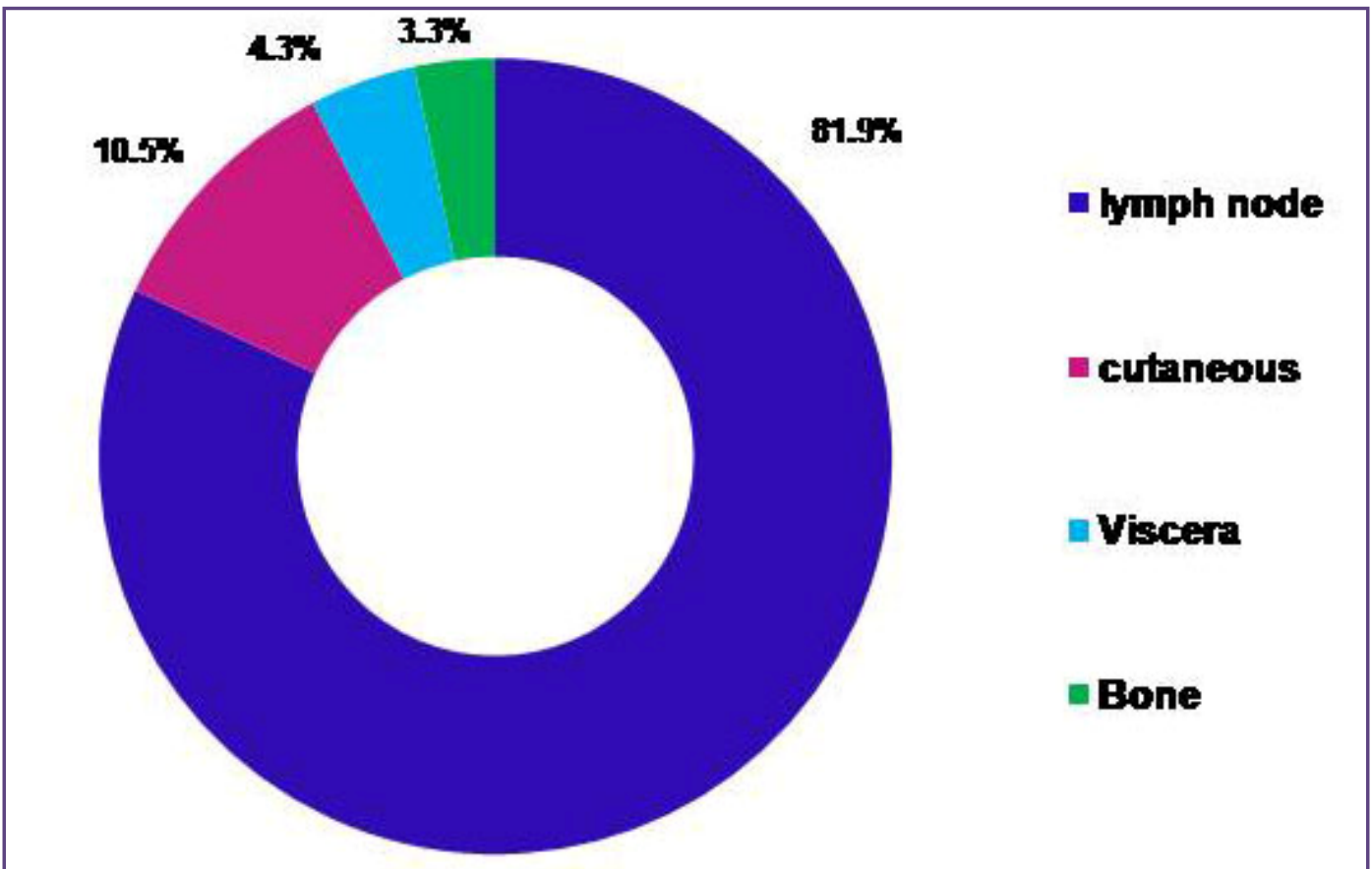

Fig. 1: Distribution of metastatic lesions in various locations.

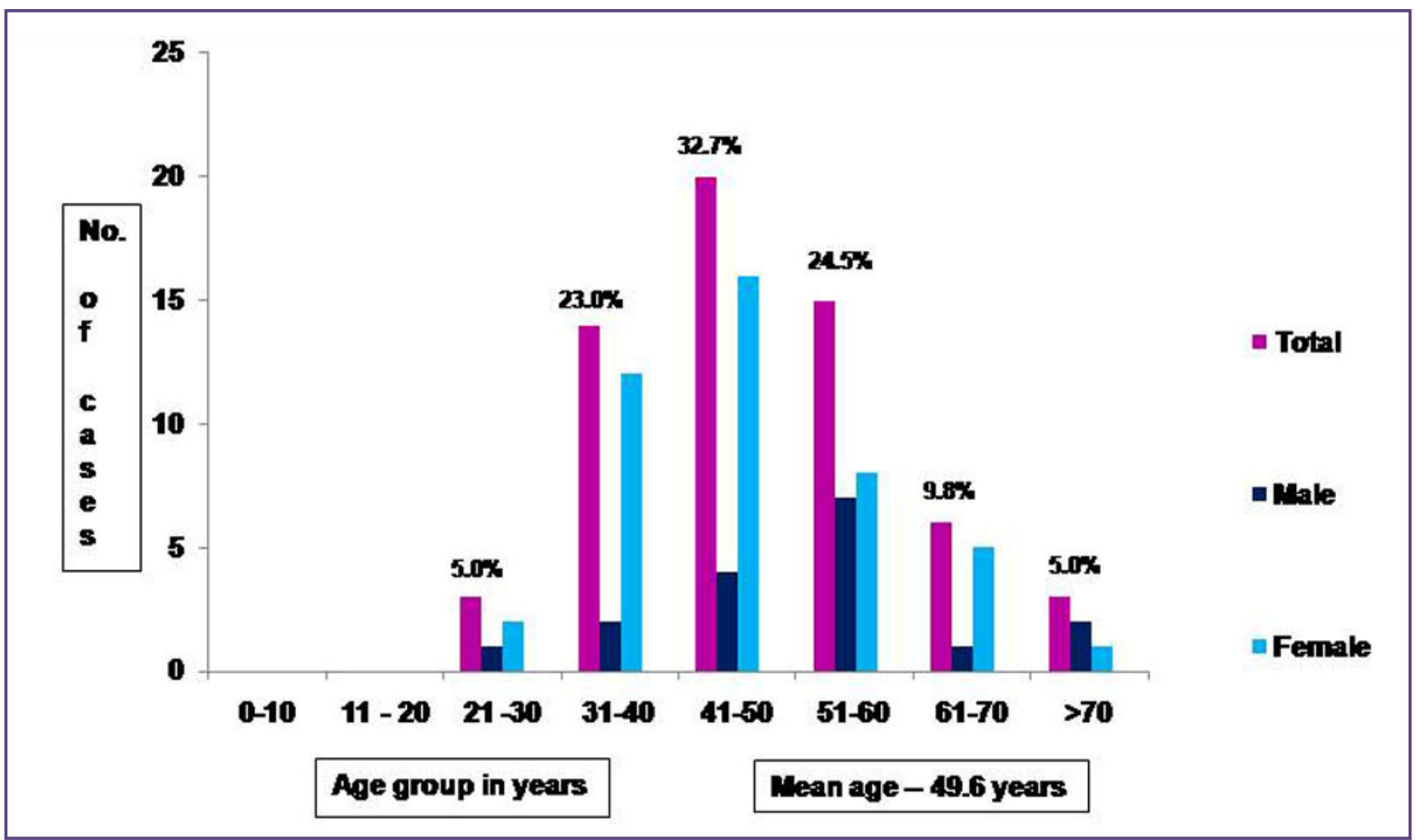

Fig. 2: Age and sex wise distribution of total cases with cutaneous metastatic lesions. 


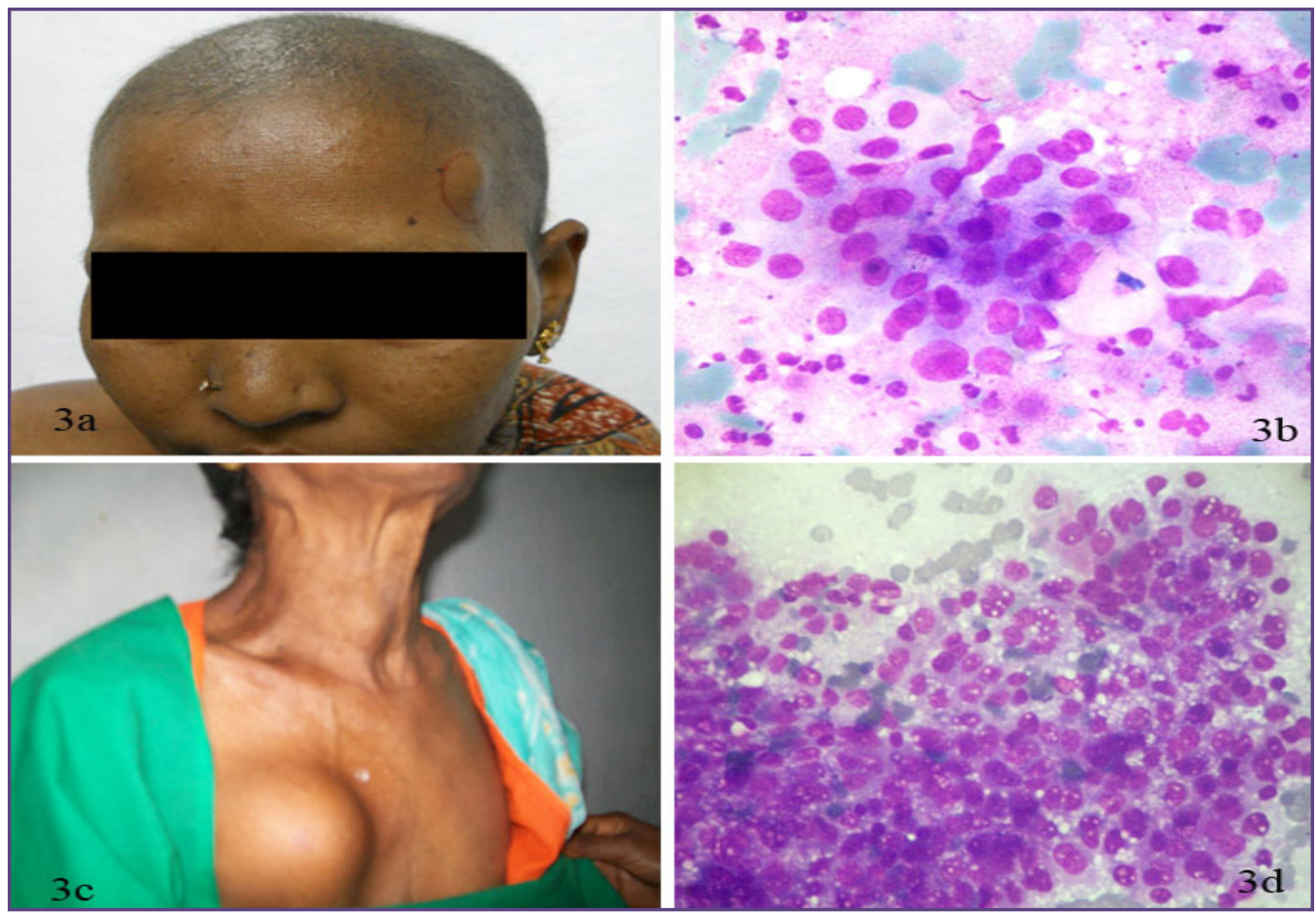

Fig. 3: Clinical and cytological findings of unusual cutaneous metastases. [3a, 3b] Clinical picture and microphotographs of FNA cytosmears (Leishman, $x$ 400) of cutaneous gastric adnocarcinomatous deposit in left forehead. [3c, 3d] Clinical picture and microphotograph of FNA cytosmears (Leishman, $\mathrm{x} 400$ ) of cutaneous metastasis in chest wall from carcinoma thyroid.

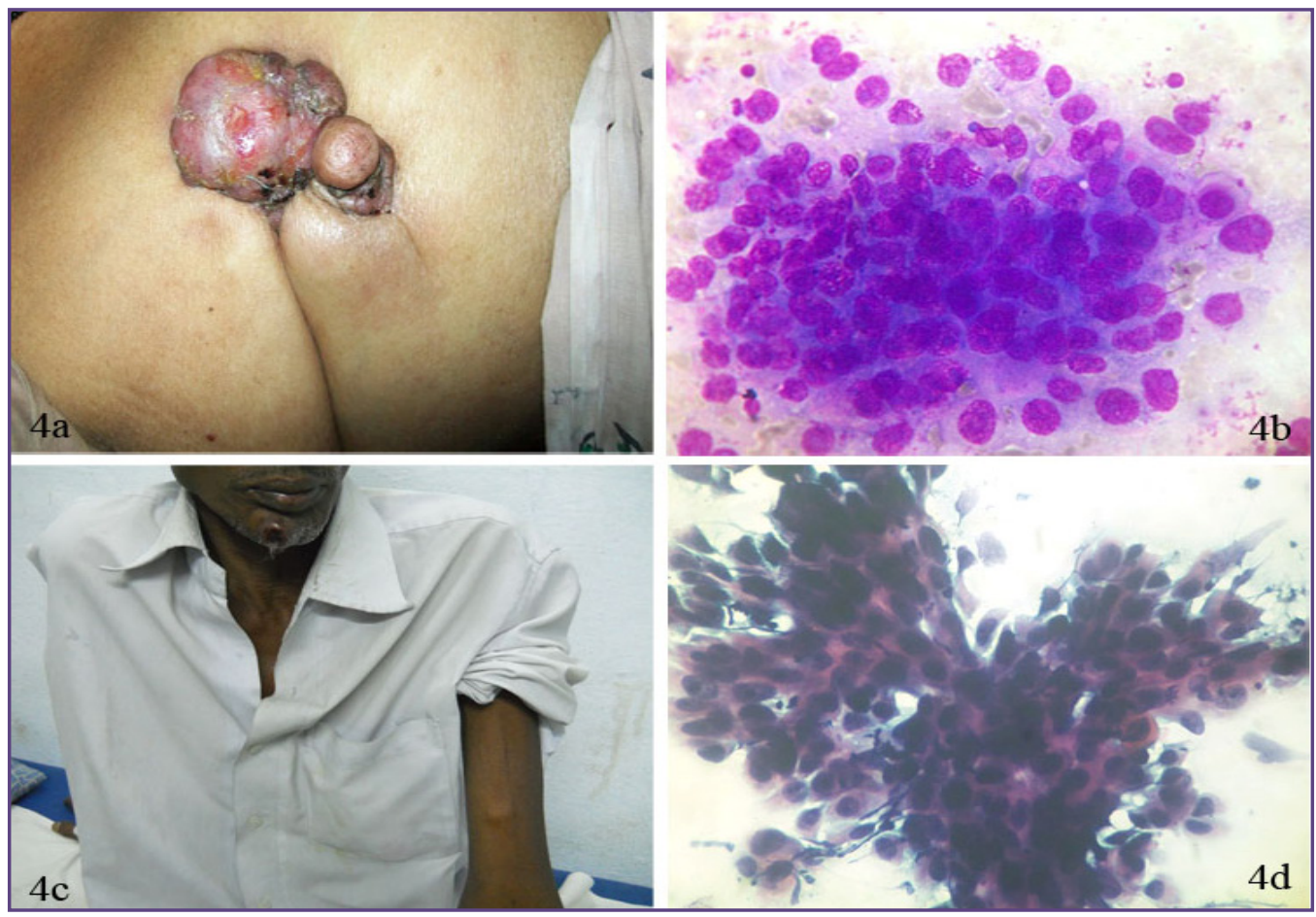

Fig. 4: Clinical and cytological findings of unusual cutaneous metastases. [4a,4b] Clinical picture and microphotographs of FNA cytosmears (Leishman, $x$ 400) of cutaneous metastasis in carcinoma breast.[4c,4d] Clinical picture and microphotograph of FNA cytosmears (Leishman, $x$ 400) of metastatic cutaneous squamous cell carcinomatous deposit from oesophagus in chin, left forearm. 

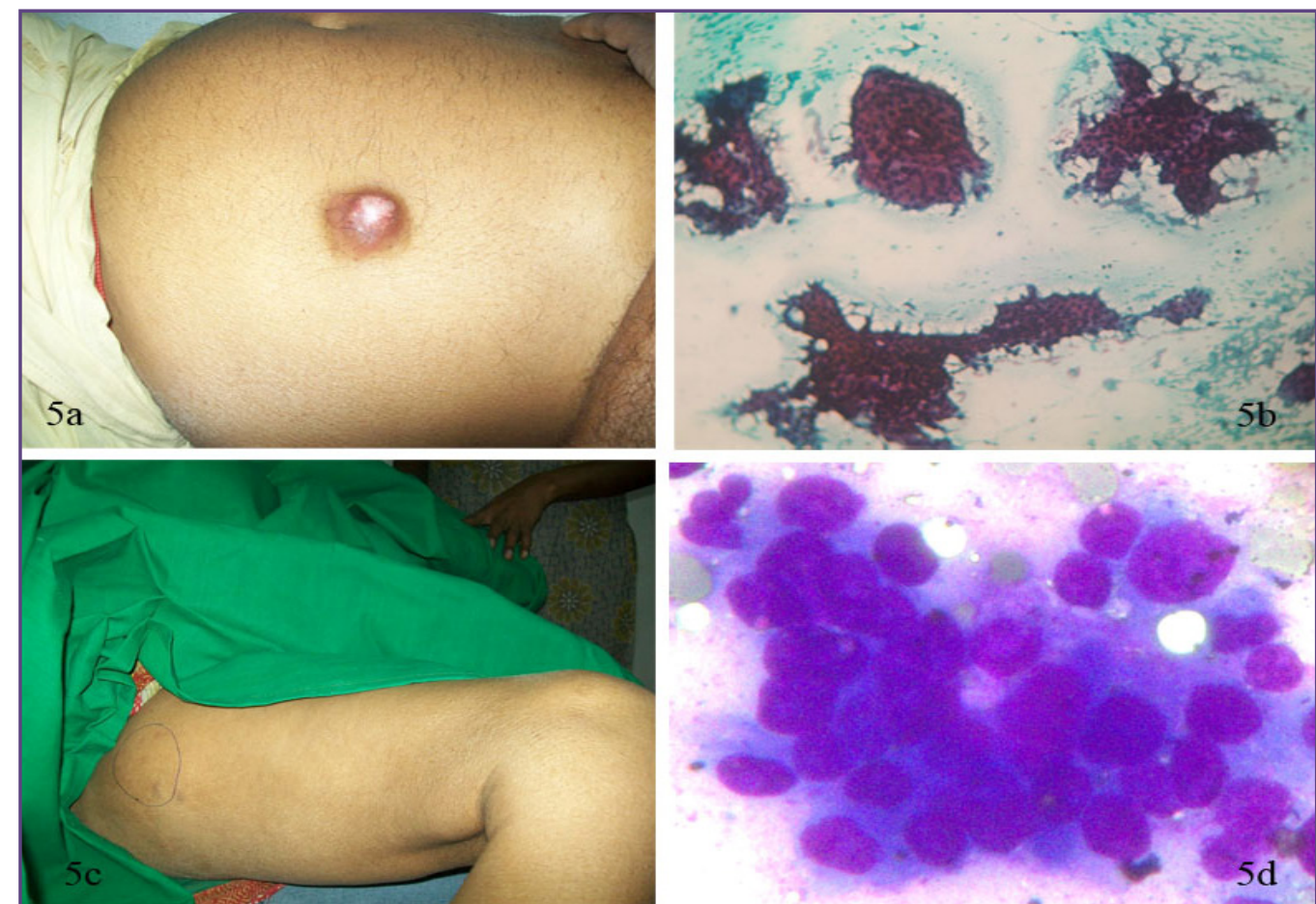

Figure 5: Clinical and cytological findings of unusual cutaneous metastases. [5a, 5b] Clinical picture and microphotographs of FNA cytosmears (Pap, $x$ 100) of urothelial carcinomatous deposit in abdomen, [5c,5d] Clinical picture and microphotographs of FNA cytosmears (Leishman, $x$ 400) of ductal adenocarcinomatous deposit in left thigh.

be the first clinical sign before the diagnosis of primary cancer i.e. an occult cancer.

Although, cutaneous metastasis is rare but it is not uncommon. In the present study, $10.5 \%$ of total 579 cases having metastatic lesions had cutaneous metastasis which is similar to study conducted by various authors describing the incidence of cutaneous metastasis to be varying from 0.5 to $10.4 \%{ }^{[1-5]}$ Out of these 61 cases with cutaneous metastatic lesions, 17 cases were males and 44 cases were females with M:F ratio of 1:2.6. This finding differs from Karki et al. and Chaudhury et al. who observed the M: F ratio to be 1:1 and 1.7:1 respectively ${ }^{[8,9]} \mathrm{Age}$ and sex wise distribution of these cases revealed that majority, 35/61 (57.2\%) cases was in 5th to 6th decade and the mean age being 49.6 years which concords with the documents depicting the incidence of cutaneous metastasis to be increasing with advancing age especially after $5^{\text {th }}$ decade. ${ }^{[10]}$

Cutaneous metastasis can have a wide spectrum of clinical presentations and broadly divided into three groups - i.) nodular - The first sign of skin metastasis is characterized by a firm, mobile, non tender nodule in skin which can be of barely noticeable lesions to a large tumor. The nodule may be skin coloured, red or blue black as in melanoma. ii) Carcinoma en cuirasse or sclerodermoid carcinoma characterized by extensive thickening, edema and fibrosis of dermis and subcutis giving rise to a sclerodermoid pattern which occurs due to infiltration of cancer cells into collagen tissue of skin. iii) Inflammatory or carcinoma erysipeloides characterized by well demarcated red patches due to local spread of primary cancer with blockage of lymphatics in adjacent skin. ${ }^{[10,11]}$ In our study, it was observed that the lesions were mostly nodular, the average size being $3.7 \mathrm{~cm}$. These findings were at par with others studies documenting nodular lesion as the most common clinical presentation of cutaneous metastasis. ${ }^{[2]}$ Cutaneous metastatic lesions are mostly multiple and rarely solitary. But, we observed maximum number of cases, $95.0 \%$ had metastasis in single site and $5.0 \%$ cases had lesions in multiple sites . Further, majority, had solitary lesion as seen in $83.6 \%$ cases. This observation is similar to that of Karki et al. who observed cutaneous metastasis in single site or as single nodule in $79.0 \%$ of their studied cases ${ }^{[8]}$ and Sharma et al. who observed multiple site involvement only in $9.0 \%$ of their studied cases. ${ }^{[12]}$

The most common site of cutaneous metastasis was observed to be chest wall which was similar to observations made by Karki et al. and Sharma et al. ${ }^{\left[{ }^{[811}\right]}$ but differed from Gupta et. al. and Pak. et al. who observed the common site for cutaneous metastasis to be abdomen and back respectively ${ }^{[13,14]}$ In the present study, majority, 42 ( 68.8\%) 
out of 61 cases revealed the features of adenocarcinoma on FNAC. Microscopically, the most common primary tumor in females was observed to be carcinoma breast which was observed in $72.7 \%$ of total 44 females. In a large case studies, Lookingbill et al. also observed carcinoma breast in $51.0 \%$ of total cases with cutaneous metastasis and $73.0 \%$ of all females. ${ }^{[2]}$ Studies conducted by Chaudhury et al., Sharma et al., and Gupta et al. also documented similar findings ${ }^{[9,11,13]}$ However, Karki et al. and Pak et al. observed colon and lung to be major primary site of cutaneous metastasis in females. ${ }^{[8,14]} \mathrm{We}$, observed both carcinoma lung and carcinoma stomach/ colon as primary site for cutaneous metastasis in males which was similar to the observations made by others. ${ }^{[8,11,14]}$

During this study, we observed six interesting cases with cutaneous metastatic lesions. The rationale behind describing these six cases is because of their rare and unusual presentation and accurate diagnosis on the basis of FNA findings. The finding of cutaneous metastasis in left forehead region in a post operative and post chemotherapy treated case of carcinoma stomach with Krukenberg's tumor was quite interesting. Gastric carcinomas usually metastatize to lymph nodes, peritoneum, liver, pancreas, colon, lung, ovary and bone. Cutaneous metastasis is rare, occurring in $0.8 \%$ of all gastric cancer cases. $[15,16]$ The most common type cutaneous metastasis is reported to be subcutaneous or intradermal nodules, but, rarely carcinoma en cuirasse pattern can also be seen. ${ }^{[1]}$ The occurrence of follicular carcinoma of thyroid as a cutaneous metastasis over chest wall is rare as the usual sites of cutaneous metastasis is in head and neck region such as scalp, forehead and neck, but can also be seen in abdomen, back and thigh. ${ }^{[18,19]}$ One of these six cases presented with cutaneous metastatic lesion in left thigh from carcinoma breast. There are eight different clinicopathological types of skin involvement from breast cancer such as inflammatory breast carcinoma, telangiectatic metastatic breast carcinoma, nodular metastatic carcinoma, alopecia neoplastica, breast carcinoma of inframammary crease, metastatatic mammary carcinoma of eyelid, Paget's disease and carcinoma en cuirasse. ${ }^{[10,20]}$ Though, the most common presentation of skin metastasis from breast carcinoma is in the form of a nodule in thoracic or abdominal wall, but it can occur in back, limb and head and neck region. ${ }^{[21,22]}$ We observed a single post operative case of carcinoma oesophagus who was diagnosed with squamous cell carcinomatous deposit in chin and upper arm. Carcinoma oesophagus has a dismal prognosis and rarely metastasizes to skin with documented incidence of $1.0 \%{ }^{[23]}$ These lesions can present clinically as papule, nodule and the common sites of metastasis are chest wall and abdomen, ${ }^{[24]}$ though rarely it can occur in digits, lower lip and scalp. ${ }^{[25-28]}$ In a large study of 7316 cancer cases with metastasis to skin, Lookingbill et al. did not observe any cutaneous metastasis from oesophageal cancer ${ }^{[29]}$ Only one case, $1.6 \%$ of total cases in this study, was diagnosed as cutaneous metastasis from carcinoma urinary bladder in abodominal wall. Cutaneous metastasis from urologic tumors is rare accounting for $1.0 \%$ of cases with advanced diseases which is more frequently observed from renal tumors followed by urinary bladder and prostate. Muller et.al from their study conducted over a period of 10 years observed overall incidence of cutaneous metastases from all the primary solid visceral malignancies to be $2.9 \%$ where kidney, urinary bladder and prostate attributed to $3.4 \%, 0.8 \%$ and $0.4 \%$ respectively. ${ }^{[30]}$

\section{Conclusion}

This study depicts the clinico-cytopathological features of cutaneous metastatic lesions as well as highlights the utility of FNAC in the diagnosis of various forms of cutaneous metastatic lesions observed in patients with known primary or unknown primaries from internal malignancy. Majority of these cases can be diagnosed accurately by skilled and experienced pathologists which helps the clinicians to take prompt decision for further therapeutic management.

\section{Acknowledgements}

The authors are thankful to Dr. P.B. Anand Rao, Professor, department of Radiotherapy and the histopathology technicians of department of Pathology, G S L Medical college and general hospital, Rajahmundry for their help and cooperation.

\section{Reference}

1. Spencer PS, Helm TN. Skin metastases in cancer patients. Cutis. 1987;39:119-121.

2. Lookingbill DP, Spangler N, Helm KF. Cutaneous metastases in patients with metastatic carcinoma: a retrospective study of 4020 patients. J Am Acad Dermatol. 1993;29:228-236

3. Schwartz RA. Cutaneous metastatic disease. J Am Acad Dermatol. 1995;33:161- 182.

4. Krathen RA, Orango IF, Rosen T. Cutaneous metastasis: a meta-analysis data. South Med. J. 2003; 96(2):164-7

5. Alcaraz I, Cerroni L, Rütten A, Kutzner H, Requena L. Cutaneous metastases from internal malignancies: A clinicopathologic and immunohistochemical review. Am J Dermatopathol.2012;34:347-93.

6. Oliveira GM, Zachetti DB, Barros HR, Tiengo A, Romiti N. Breast carcinoma en Cuirasse- case report. An Bras Dermatol. 2013;88:608-10.

7. Sittart JA, Senise M. Cutaneous metastasis from internal carcinomas: a review of 45 years. An Bras Dermatol. 2013;88:541-4. 
8. Karki S, Pathak R, Manandhar U, Koirala S. Metastatic cutaneous and subcutaneous lesions: Analysis of cases diagnosed on fine needle aspiration cytology. Journal of Pathology of Nepal 2011;1:37-40

9. Chaudhury SK, Bandopadhya R, Mukhopadhaya S, Nag D, Sinha SK. FNAC of cutaneous metastatic nodules: a clinicopathological study with review of literature. AI Ameen J Med Sci 2013;6:202-7

10. Rolz-Cruz G, Kim CC. Tumor invasion of the skin. Dermatol. Clin. 2008;26:89-102. PMid:18023773.http:// dx.doi.org/10.1016/j.det.2007.08.004

11. Sánchez-Muñoz A, Gravalos Castro C, Colomer Bosch R, García Velasco A, García JP, Cortés-Funes H. Generalized cutaneous-nodal metastatic spread as initial manifestation of the recurrence of a gastric adenocarcinoma. Rev Clin Esp. 2003;203:597-8

12. Sharma S, Kotru M, Yadav A, Chugh M, Chawla A, Makhija M. Role of fine needle aspiration cytology in evaluation of cutaneous metastasis. Diagn Cytopathol 2009;37:876-80

13. Gupta RK, Naran S. Fine needle aspiration cytology of cutaneous and subcutaneous metastatic deposits from epithelial malignancies. An analysis of 146 cases. Acta Cytol. 1999;43:126-30

14. Pak HY, Foster BA, Yokata SB. The significance of cutaneous metastasis from visceral tumors diagnosed by fine needle aspiration study. Diagn. Cytopathol. 1987;3:24-9

15. Kavgaci H, Reis A, ozedmir F, Bektas O, Arslan M, Aydin F. Carcinoma erysipelatoides resulting from gastric adenocarcinoma: An unusual clinical presentation. Med Princ Pract. 2005; 14:61-3[PubMed]

16. Hu SC, Chen GS, Wu CS, Chai CY, Chen WT, Lan CC. Rates of cutaneous metastases from different internal malignancies: Experience from a Taiwanese medical centre. J Am Acad Dermatol. 2009;60:379-87

17. Kaur S, Aggarwal P, Dayal S, Sagwan A, Jain VK, Jindal N. Cutaneous metastasis from signet ring gastric adenocarcinoma in a carcinoma En Cuirasse pattern: An unusual clinical diagnostic sequence. Indian J Dermatol. 2015;60:637.doi:10.4103/0019-5154.169162.

18. Agarwal S, Rao S, Arya A, Gupta K, Arora R, Dhawan I. Follicular thyroid carcinoma with metastasis to skin diagnosed on fine needle aspiration cytology. Indian $\mathrm{J}$ Pathol. Microbiol.2008;51:430-1

19. Rahman GA, Abdulkadir AY, Olatoke SA, Yusuf IF, Braimoh KT. Unusual cutaneous metastatic follicular thyroid carcinoma. J Surg Tech Case Rep. 2010;2:35-8. doi: 10.4103/2006-8808.63724

20. Schwartz RA. Histopathologic aspects of cutaneous metastatic disease. J Am Acad Dermatol. 1995;33:649-57. http://dx.doi.org/10.1016/0190-9622(95)91288-6

21. Nava G, Greer Kenneth, Patterson J , Lin KY. Metastatic cutaneous breast carcinoma:A case report and review of literature.Can J Plast Surg. 2009:17:15-17.PMC2705310

22. Bittecourt MJS, Carvalho AH, Nascimento BAM, Freitas LKM, Parijos AM. Cutaneous metastasis of breast cancer diagnosed 13 years before. An. Bras. Dermatol. 2015;90 (3 Suppl.1):S134-7

23. Quint LE, Hepburn LM, Francis IR, Whyte RI, Orringer MB. Incidence and distribution of distant metastases from newly diagnosed esophageal carcinoma. Cancer 1995;76:1120-5

24. Baijal R, Hassan PK, Jain M, Gupta D, Shah N. Cutaneous metastasis in esophageal squamous cell carcinoma. Indian J Med Paediatr Oncol. 2013 ; 34(1): 42-43. doi: 10.4103/0971-5851.113428

25. Yi JH, Moon WS, Yun Sk, Kim HU, Ihm CW. Clinicopathological study on metastatic skin cancer. Korean J Dermatol. 2006;44:567-73

26. Shin JH, Jeong CW, Min HG, Lee ES. Two cases of cutaneous metastases originating from oesophageal carcinoma. Korean J Dermatol. 2000;38:971-4

27. Kim CW, Kim YJ, Kim SY, Nam SH, Lee JJ. A case of squamous cell carcinoma metastatized from oesophageal carcinoma. Korean J Dermatol.2002;40:983-5

28. Park JM, Dae SK, Sang HH, Yeon SK, Kwang HL. A case of esophageal adenocarcinoma metastatized to scalp. Ann. Dermatol.2009;21:164-7

29. Lookingbill DP, Spangler N, Sexton FM. Skin involvement as the presenting sign of internal carcinoma. A retrospective study of 7316 cancer patients. J Am Acad Dermatol. 1990;22:19-26

30. Muller TJ, Wu H, Greenberg RE, Hudes G, Topham N, Lessin SR, Uzzo RG. Cutaneous metastases from genitourinary malignancies. Urology 2004;63:1021-6.

*Corresponding author:

Dr. Manisha Mohapatra, MD, PhD, Professor, Department of Pathology, GSL Medical College \& General Hospital, NH-16, Lakshmipuram-533296 Rajahmundry, Andhra Pradesh India

Email: manisha.mahapatra1@gmail.com

Financial or other Competing Interests: None. 